\title{
Screening for thyroid disease in a primary care unit with a thyroid stimulating hormone assay with a low detection limit
}

\author{
R Eggertsen, K Petersen, P-A Lundberg, E Nyström, G Lindstedt
}

Mölnlycke Primary Care Centre and Department of Primary Health Care, Gothenburg University, Centralvägen 18, S-435 00 Mölnlycke, Sweden $\mathrm{R}$ Eggertsen, $\mathrm{MD}$, associate professor, head physician

Sahlgren's Hospital, Gothenburg University, S-413 45 Gothenburg, Sweden

$\mathrm{K}$ Petersen, $\mathrm{MD}$, research associate, department of medicine II

P-A Lundberg, BSC, chief technician, department of clinical chemistry E Nyström, MD, associate professor, senior lecturer, department of medicine II $\mathrm{G}$ Lindstedt, MD, professor of clinical chemistry

Correspondence to: $\mathrm{Dr}$ Nyström.

\begin{abstract}
In a study at a primary care centre in a predominantly rural area of Sweden the records of all patients with established thyroid disease were scrutinised and 2000 consecutive adult patients screened with an immunoenzymometric thyroid stimulating hormone assay. The aims of the study were fourfold: firstly, to assess the total burden of thyroid disease in primary care centres in Sweden; secondly, to assess the efficacy of clinical diagnosis of the disease in unselected populations of patients; thirdly, to assess the efficacy of clinical evaluation of treatment with thyroxine; and, lastly, to see whether a single analysis of the serum thyroid stimulating hormone concentration by recent methods would be enough to identify an abnormality of thyroid function.

Of the roughly 17400 adults in the study community, 111 women and 10 men were being treated for thyroid disease. Screening detected 68 patients (3.5\%) not receiving thyroxine who had a serum thyroid stimulating hormone concentration of $0 \cdot 20$ $\mathrm{mU} / \mathrm{l}$ or less, all of whom were followed up clinically. Fifty of these patients were also studied biochemically during follow up. Only nine of the 68 patients had thyroid disease (three with thyrotoxicosis requiring treatment), no evidence of the disease being found in the remainder. Sixteen patients had spontaneous hypothyroidism requiring treatment, and neither these nor three patients with thyrotoxicosis had been detected at the preceding clinical examination. Of 35 patients in whom thyroid disease was suspected clinically at screening, none had laboratory evidence of thyroid dysfunction.

In this series $1.3 \%$ of all women in the study community (2.6\% of all $50-59$ year olds) and $0 \cdot 1 \%$ of the men were being treated for thyroid disease at the primary care centre, roughly $1.0 \%$ of adults subjected to screening were found to have thyroid disease requiring treatment, and most patients with a thyroid stimulating hormone concentration of $\mathbf{0 . 2 0}$ $\mathrm{mU} / \mathrm{l}$ or less did not have thyroid dysfunction. It is concluded that measuring the basal serum thyroid stimulating hormone concentration by present methods is insufficient for the biochemical assessment of thyroid dysfunction in unselected populations.
\end{abstract}

\section{Introduction}

Autoimmune thyroid disease is a common endocrine disorder, predominantly affecting women. Thus the prevalence of treated spontaneous hypothyroidism in the Whickham study was roughly $1.0 \%$ among women aged over 18 compared with less than $0.1 \%$ in the male population. ${ }^{1}$ In the same study the prevalence of hyperthyroidism in women was reportedly about $1.9 \%$ $(0 \cdot 16 \%$ in men). Some $25-80 \%$ of hyperthyroid women may later develop hypothyroidism as a result of subtotal thyroidectomy or various schemes of radioiodine treatment. ${ }^{2}$ The prevalence of undiagnosed thyroid dysfunction (hypothyroidism or hyperthyroidism) in the female population has been reported to be $0 \cdot 3-0 \cdot 6 \%$ and $0 \cdot 5-0 \cdot 6 \%{ }^{3}$

In Sweden the detection and management of patients with thyroid disease is mostly undertaken at primary care level, so forming an important part of the work of primary care centres. We have shown that clinical methods of diagnosing thyroid disease in unselected patient populations at medical outpatient departments have poor sensitivity and specificity. ${ }^{4}$ This paper examines the prevalence of established and undiagnosed thyroid disease in a primary care centre serving a population representative of that of Sweden as a whole. The study aimed at $(a)$ estimating the total burden of thyroid disease in primary care centres in Sweden, $(b)$ assessing the efficacy of clinical diagnosis of thyroid disease in unselected patient populations, $(c)$ assessing the efficacy of clinical evaluation of thyroxine treatment, and $(d)$ evaluating proposals that single analysis of the serum thyroid stimulating hormone concentration by recent methods would be enough to identify abnormal thyroid function.

\section{Study population and methods}

Mölnlycke is situated in a predominantly rural area close to Gothenburg on the Swedish west coast. Of the 24800 residents served by the primary care centre, about 17400 are aged 18 or over with roughly equal numbers of men and women. Every year the centre sees around 21000 patients, either as scheduled appointments or for new disorders or minor emergencies.

During a period of three years we recorded all patients with thyroid disease who attended the centre. At the end of the period (October 1986) we started screening for thyroid disease in 2000 consecutive adult patients attending the centre for routine care or for minor emergencies or new disorders. In all cases screening included analysis of the serum thyroid stimulating hormone concentration. All patients received a written explanation of the study, which was approved by the ethical committee of the University of Gothenburg, and were asked to agree to blood sampling in case screening comprised only the laboratory test. The six physicians and other members of staff at the centre were informed that evaluation of thyroid dysfunction was a goal of the study. For all patients screened a clinical assessment of thyroid function and of gross morphology of the thyroid was performed and information recorded about the reason for the visit, drug treatment (including dose and time of intake), smoking habits, and any other relevant clinical data. Blood was sampled with the patients semirecumbent. Samples were centrifuged and aliquots of serum frozen 
in sealed phials on sampling days, a separate aliquot being stored at $4^{\circ} \mathrm{C}$ for assay of serum thyroid stimulating hormone and free thyroxine concentrations within the next few days. For practical reasons patients arriving after $3 \mathrm{pm}$ were excluded from the study.

Patients with test results outside the stated limits were contacted within a few days to arrange a second blood sample after two to three weeks. Follow up of patients with persistent abnormality included clinical examination, detailed medical history, and, when appropriate, a stimulation test with protirelin (thyroid stimulating hormone releasing hormone), thyroid radioiodine uptake tests, (technetium-99m) pertechnetate scintigraphy, and fine needle biopsy. In all patients with thyroid disease (established or newly diagnosed) relevant information about thyroid and other diseases was recorded as well as medical treatment. Efforts were made to trace all medical records (including any from other hospitals) for information on thyroid disease. The final diagnosis of hyperthyroidism or hypothyroidism was made at least six months after initiation of treatment. As the design of the screening study did not include recommendations about the time of intake of drugs in relation to blood sampling - and specifically as the time of intake of thyroxine is relevant to serum concentrations of thyroid stimulating hormone and free thyroid hormones - we recalled 30 patients receiving thyroxine supplementation after completion of the screening study and instructed those who returned to take their daily dose after blood sampling.

\section{ASSAYS}

Assays of thyroid stimulating hormone and free thyroxine concentrations were usually performed within two days after blood sampling in order to allow an early decision about recalling the patient; other assays were done later. Precision of the assays was assessed with four different types of pooled serumnamely, $(a)$ serum from patients with high free thyroxine concentrations, (b) serum from blood donors (predominantly men), (c) serum from middle aged and early postmenopausal women, and $(d)$ serum from patients with high thyroid stimulating hormone concentrations. In some runs we had to delete single controls because of lack of reagents. As indicated below, changes to a new batch were done during the study for some pools. Controls were included at the beginning and end of each run. Samples used for calibration and from controls and patients were analysed in duplicate.

Serum thyroid stimulating hormone concentration was determined with an immunoenzymometric assay (Abbott Laboratories, north Chicago) with a detection limit of $0.05 \mathrm{mU} / \mathrm{l}$. The "capture" antibodies are two $\beta$ specific monoclonal antibodies bound to a bead, and the "signal" antibody is the $F_{a b}$ fragment of an $\alpha$ specific monoclonal antibody conjugated with horseradish peroxidase. The analysis was carried out according to the manufacturer's instructions, by using manual procedures throughout. Table II shows the within assay precision profile for patients' specimens expressed as the coefficient of variation at different ranges of concentrations. The total between assay coefficient of variation for control samples with a high free thyroxine concentration was $25 \cdot 8 \%$ at the beginning of the assay run and $26.3 \%$ at the end (mean concentrations 0.296 and $0.294 \mathrm{mU} / \mathrm{l}$, respectively; No of runs $=132$ ). Coefficients of variation for "euthyroid" pools were $11.6 \%$ and $12.3 \%$ (mean concentration $1.2 \mathrm{mU} / \mathrm{l}$ both at the beginning and at the end) and $8.9 \%$ and $8.2 \%$ (mean concentrations 1.91 and $1.92 \mathrm{mU} / 1$, respectively; $\mathrm{n}=132$ ). For two different pools with a high thyroid stimulating hormone concentration coefficients of variation were $6 \cdot 8 \%$ and $6 \cdot 1 \%$ (mean concentrations
16.4 and $16.4 \mathrm{mU} / \mathrm{l} ; \mathrm{n}=74$ ) and $7.6 \%$ and $9.0 \%$ (mean concentrations 39.7 and $39.4 \mathrm{mU} / \mathrm{l} ; \mathrm{n}=83$ ); both control assays were run during a transition period. These results indicated identical performance of the assay during the run without drift. Time series analysis indicated absence of assay drift during the study.

In order to find samples giving falsely raised values caused by heterophilic antibodies we reassayed all samples giving values which were unexpectedly high in relation to clinical information and free thyroxine values. For repeat assays we used two immunoradiometric procedures (RIAgnost hTSH (human thyroid stimulating hormone), Behringwerke AG, Marburg, West Germany; and SPECTRIA TSH IRMA (thyroid stimulating hormone immunoradiometric assay) (iodine-125), Farmos Diagnostica, Turku, Finland) and one radioimmunoassay (NHS-TSH (normal human serum-thyroid stimulating hormone) double antibody, Diagnostic Products Corporation, Los Angeles). The immunoenzymometric thyroid stimulating hormone assay had previously been used in the routine biochemical investigation of patients referred to our hospital for thyroid disease, and patients with established hyperthyroidism consistently had undetectable values.

Free thyroxine concentration was determined with a ${ }^{125}$ I labelled analogue radioimmunoassay (Coat-ACount free thyroxine; Diagnostic Products, Los Angeles $)^{6}$ as modified by the manufacturer. Performance of the assay was similar to that reported for the original version. The "euthyroid" serum controls were those used in determining thyroid stimulating hormone concentrations, whereas we used other pools with high and borderline to low free thyroxine concentrations. There were 76 assay runs; the total between assay coefficients of variation at the beginning and end of the runs (mean concentrations in parentheses) were: for 31 runs with pooled serum containing high free thyroxine concentration $5 \cdot 8 \%(43.7 \mathrm{pmol} / \mathrm{l})$ and $7 \cdot 8 \%$ $(42.9 \mathrm{pmol} / \mathrm{l})$, and for 45 runs with another pooled serum containing high free thyroxine concentrations $6.5 \%(46.7 \mathrm{pmol} / \mathrm{l})$ and $8 \cdot 1 \%(46.2 \mathrm{pmol} / \mathrm{l})$; for runs with pooled serum from blood donors $5.7 \%$ $(15 \cdot 5 \mathrm{pmol} / \mathrm{l})$ and $7 \cdot 2 \%(15 \cdot 1 \mathrm{pmol} / \mathrm{l})$; for runs with pooled serum from middle aged and early postmenopausal women $6.4 \%(15.3 \mathrm{pmol} / \mathrm{l})$ and $6.9 \%$ $(15.3 \mathrm{pmol} / \mathrm{l})$; and for pooled serum containing high thyroid stimulating hormone concentrations $6 \cdot 2 \%$ $(9 \cdot 11 \mathrm{pmol} / \mathrm{l})$ and $7 \cdot 6 \%(9 \cdot 07 \mathrm{pmol} / \mathrm{l})$. Thus, though there was a trend towards lower precision at the end of the run, there was negligible, if any, within assay bias. There was no drift during the study.

Total thyroxine concentration was determined with a single antibody macrogol (polyethylene glycol) radioimmunoassay (thyroxine $\left({ }^{125} \mathrm{I}\right)$ radioimmunoassay kit; Farmos Diagnostica, Turku) and free 3,5,3'triiodothyronine concentration with a ${ }^{125}$ I labelled analogue radioimmunoassay (Amerlex-M free $\mathrm{T} 3$; Amersham International, United Kingdom). Total $3,5,3^{\prime}$-triiodothyronine concentration was determined with a double antibody macrogol radioimmunoassay (T3 RIA double antibody; Diagnostic Products, Los Angeles), in all cases with free thyroxine $>21.0 \mathrm{pmol} / \mathrm{l}$. Thyroxine binding globulin was determined by a single antibody macrogol radioimmunoassay (RIA-gnost TBG; Behringwerke AG, Marburg). Serum microsomal antibodies were determined with a ${ }^{125}$ I-protein A sandwich method (PROMAK) and thyroid stimulating hormone receptor antibodies by a ${ }^{125}$ I-thyroid stimulating hormone competition method (TRAK; Henning Berlin GmbH, West Berlin). Table IV lists the decision limits used in the study. Details of performance of the assays will be reported separately. In patients with microsomal antibodies and thyroid stimulating hormone concentrations of 
$0.20 \mathrm{mU} / 1$ or less we also used an immunofluorescence method (thyroid antibody test system and mitochondrial antibody test system; SciMedX, Denville, New Jersey). Screening for antibodies binding to the thyroxine analogue used in measuring the free thyroxine concentration was performed as described. Further evaluation in these cases and of patients with other abnormal binders was done by electrophoresis in agarose gel after incubation with each of several labelled ligands. ${ }^{8}$

The protirelin (thyroid stimulating hormone releasing hormone) stimulation test was carried out with the patient semirecumbent. Blood was drawn from an indwelling venous catheter flushed with saline. Heparin was not used. Five specimens were taken at 10 minute intervals. Protirelin $200 \mu \mathrm{g}$ (TRH-Roche) was given through the catheter immediately after drawing the second specimen. A positive response was taken as a rise of $0.10 \mathrm{mU} / 1$ or more in the last two specimens compared with the first two, the maximal thyroid stimulating hormone response being calculated as the maximal difference in relation to the specimen taken immediately before protirelin.

\section{Results}

CROSS SECTIONAL STUDY

Altogether 111 women and 10 men - that is, $1.3 \%$ of all women in the study community and $0.1 \%$ of the men-were being treated for thyroid disease at the primary care centre. The largest proportion at any age $(2 \cdot 6 \%)$ was among women aged $50-59$ (table I).

\section{PERFORMANCE OF THYROID STIMULATING HORMONE ASSAY}

The within assay coefficient of variation for the immunoenzymometric thyroid stimulating hormone assay was calculated from the differences between duplicate analyses of all samples (screening plus recall). Table II gives the results for thyroid stimulating hormone concentrations ranging from 0.05 to $100 \mathrm{mU} / \mathrm{l}$. As expected, imprecision was high (coefficient of variation $\geqslant 9.9 \%$ ) at low thyroid stimulating hormone concentrations $(<0.7 \mathrm{mU} / \mathrm{l})$, whereas coefficients of variation of around $5 \%$ or less were generally recorded at thyroid stimulating hormone concentrations of $>2 \cdot 0 \mathrm{mU} / 1$.

\section{SCREENING STUDY}

Over about three months we screened 2000 consecutive adults who attended the primary care centre, serum thyroid stimulating hormone concentrations of 0.20 and $4.0 \mathrm{mU} / 1$ being taken as the lower and upper decision limits for recall. (These limits corresponded to the 3.5 and 96.5 centiles as calculated for 1929 of the 2000 patients, 71 receiving thyroxine supplementation being excluded.) Altogether screening detected nine patients with a serum thyroid stimulating hormone concentration of $\leqslant 0.20 \mathrm{mU} / 1$ and thyroid disease (table III). Table IV shows the laboratory and clinical

TABLE I-Age and sex distribution of adults in study community being treated for thyroid disease at primary care centre, 1984-6

\begin{tabular}{|c|c|c|c|c|c|c|}
\hline \multirow{2}{*}{$\begin{array}{l}\text { Age } \\
\text { (years) }\end{array}$} & \multicolumn{2}{|c|}{ Men } & \multicolumn{2}{|c|}{ Women } & \multicolumn{2}{|c|}{ Total } \\
\hline & No & $\%$ & No & $\%$ & No & $\%$ \\
\hline $18-<20$ & $0 / 420$ & & $0 / 390$ & & $0 / 810$ & \\
\hline $20-29$ & $2 / 1500$ & $0 \cdot 1$ & $3 / 1400$ & $0 \cdot 2$ & $5 / 2900$ & $0 \cdot 2$ \\
\hline $30-39$ & $1 / 2500$ & $<0.1$ & $14 / 2400$ & 0.6 & $15 / 4900$ & $0 \cdot 3$ \\
\hline $40-49$ & $1 / 1600$ & 0.1 & $25 / 1600$ & 1.6 & $26 / 3200$ & 0.8 \\
\hline $50-59$ & $4 / 1200$ & $0 \cdot 3$ & $29 / 1100$ & $2 \cdot 6$ & $33 / 2300$ & $1 \cdot 4$ \\
\hline $60-69$ & $1 / 830$ & $0 \cdot 1$ & $19 / 920$ & $2 \cdot 1$ & $20 / 1800$ & $1 \cdot 1$ \\
\hline 70-79 & $1 / 510$ & $0 \cdot 2$ & $18 / 660$ & $2 \cdot 7$ & $19 / 1200$ & $1 \cdot 6$ \\
\hline$\geqslant 80$ & $0 / 150$ & & $3 / 270$ & $1 \cdot 1$ & $3 / 420$ & 0.7 \\
\hline Total & $10 / 8700$ & $0 \cdot 1$ & $111 / 8700$ & $1 \cdot 3$ & $121 / 17+n)$ & $0 \cdot 7$ \\
\hline
\end{tabular}

TABLE II-Within assay coefficient of variation of immunoenzymometric thyroid stimulating hormone assay (detection limit $0.05 \mathrm{mU} / \mathrm{l}$ ), calculated differences between duplicate analyses of samples from 2000 consecutive patients attending primary care unit (screening plus follow up samples)

\begin{tabular}{lccc}
\hline $\begin{array}{l}\text { Range of thyroid } \\
\text { stimulating hormone } \\
\text { concentrations }\end{array}$ & $\begin{array}{c}\text { No of } \\
\text { samples }\end{array}$ & $\begin{array}{c}\text { Mean } \\
(\mathrm{mU} / \mathrm{l})\end{array}$ & $\begin{array}{c}\text { Coefficient of } \\
\text { variation } \\
(\%)\end{array}$ \\
\hline $0 \cdot 05-0 \cdot 10$ & 14 & $0 \cdot 07$ & 61 \\
$0 \cdot 11-0 \cdot 20$ & 60 & $0 \cdot 16$ & 23 \\
$0 \cdot 21-0 \cdot 30$ & 86 & $0 \cdot 26$ & 16 \\
$0 \cdot 31-0 \cdot 40$ & 127 & $0 \cdot 36$ & 14 \\
$0 \cdot 41-0 \cdot 50$ & 154 & $0 \cdot 46$ & 13 \\
$0 \cdot 51-0 \cdot 60$ & 171 & $0 \cdot 55$ & $9 \cdot 9$ \\
$0 \cdot 61-0 \cdot 70$ & 169 & $0 \cdot 65$ & 10 \\
$0 \cdot 71-0 \cdot 80$ & 131 & $0 \cdot 75$ & $8 \cdot 3$ \\
$0 \cdot 81-0 \cdot 90$ & 134 & $0 \cdot 86$ & $7 \cdot 5$ \\
$0 \cdot 91-1 \cdot 00$ & 132 & $0 \cdot 96$ & $7 \cdot 3$ \\
$1 \cdot 01-1 \cdot 25$ & 264 & $1 \cdot 13$ & $7 \cdot 6$ \\
$1 \cdot 26-1 \cdot 50$ & 155 & $1 \cdot 37$ & $6 \cdot 5$ \\
$1 \cdot 51-1 \cdot 75$ & 117 & $1 \cdot 61$ & $6 \cdot 7$ \\
$1 \cdot 76-2 \cdot 00$ & 79 & $1 \cdot 87$ & $5 \cdot 6$ \\
$2 \cdot 01-2 \cdot 50$ & 77 & $2 \cdot 25$ & $4 \cdot 8$ \\
$2 \cdot 51-3 \cdot 00$ & 52 & $2 \cdot 73$ & $5 \cdot 2$ \\
$3 \cdot 01-4 \cdot 00$ & 62 & $3 \cdot 49$ & $5 \cdot 5$ \\
$4 \cdot 01-5 \cdot 00$ & 38 & $4 \cdot 43$ & $4 \cdot 9$ \\
$5 \cdot 01-10 \cdot 0$ & 47 & $6 \cdot 81$ & $5 \cdot 2$ \\
$10 \cdot 01-20 \cdot 00$ & 14 & $13 \cdot 8$ & $3 \cdot 7$ \\
$20 \cdot 01-30 \cdot 00$ & 7 & $25 \cdot 4$ & $4 \cdot 2$ \\
$30 \cdot 01-40 \cdot 00$ & 5 & $35 \cdot 8$ & $3 \cdot 2$ \\
$40 \cdot 01-100 \cdot 00$ & 3 & $72 \cdot 5$ & $7 \cdot 4$ \\
\hline
\end{tabular}

TABLE III-Clinical conditions associated with low serum thyroid stimulating hormone concentrations $(\leqslant 0 \cdot 20 \mathrm{mU} / \mathrm{l})$ detected at screening with immunoenzymometric assay. Figures are numbers of patients

\begin{tabular}{|c|c|c|}
\hline Diagnosis & $\begin{array}{l}\text { No with low } \\
\text { thyroid stimulating } \\
\text { hormone } \\
\text { concentration } \\
\text { detected at } \\
\text { screeening }\end{array}$ & $\begin{array}{c}\text { No attending for } \\
\text { recall study/No } \\
\text { with low thyroid } \\
\text { stimulating } \\
\text { hormone } \\
\text { concentration at } \\
\text { recall }\end{array}$ \\
\hline Thyroid disease, hyperthyroidism & 3 & $3 / 3$ \\
\hline Multinodular goitre & 2 & $2 / 2$ \\
\hline Toxic single nodule & 1 & $1 / 1$ \\
\hline Euthyroid thyroid disease & 6 & $6 / 6$ \\
\hline Multinodular goitre & 3 & $3 / 3$ \\
\hline Subacute thyroiditis & 1 & $1 / 1$ \\
\hline Postpartum thyroiditis & 1 & $1 / 1$ \\
\hline Single nodule & 1 & $1 / 1$ \\
\hline Carrier protein abnormality (?) & 1 & $1 / 1$ \\
\hline Arthritis, ibuprofen treatment ${ }^{\star}$ & 1 & $1 / 1$ \\
\hline Non-thyroid disease & 58 & $46 / 19$ \\
\hline Acute infectious disease $\nmid$ & 21 & $20 / 7$ \\
\hline Miscellaneous minor conditions $\ddagger$ & 11 & $7 / 2$ \\
\hline Depression & 11 & $7 / 3$ \\
\hline Cardiovascular disease & 6 & $5 / 3$ \\
\hline Chronic inflammatory disease $₫$ & 4 & $4 / 4$ \\
\hline $\begin{array}{l}\text { Malignancy } \\
\end{array}$ & 2 & १ \\
\hline Diabetes mellitus & 2 & $2 / 0$ \\
\hline Early pregnancy & 1 & $1 / 0$ \\
\hline
\end{tabular}

*Young woman receiving ibuprofen for mild arthritis. Borderline to low free thyroid hormone concentrations; low concentrations of total thyroxine $(37 \mathrm{nmol} / \mathrm{l})$ and triiodothyronine $(0 \cdot 84 \mathrm{nmol} / \mathrm{l})$; normal concentration of thyroxine binding globulin found by radioimmunoassay $(18 \mathrm{mg} / \mathrm{l})$; undetectable thyroid stimulating hormone concentration before and after protirelin. Withdrawal of ibuprofen resulted in return of basal thyroid stimulating hormone value to normal $(0.7 \mathrm{mU} / 1$; patient refused protirelin test).

Includes one case of upper respiratory tract infection, probably of viral thes of viral aetiolegy, with borderline to high free trilodothyronine and thyroxine concentrations, no response to protirelin, but otherwise no evidence of

$\ddagger$ Category includes minor surgery, medical ailments, and orthopaedic complaints.

Includes two patients receiving long term corticosteroids and one case of chronic active hepatitis with very high concentrations of microsomal antibodies but no other evidence of thyroid disease (see text). १Not recalled.

findings in patients with autonomous thyroid function at follow up. The three women with previously undiagnosed hyperthyroidism (cases 1-3) were treated with radioiodine. One man and one woman with transient hyperthyroidism (cases 4 and 5; subacute thyroiditis and postpartum thyroidititis) were followed up until biochemical values returned to normal. Two patients with multinodular goitre were euthyroid and received no treatment.

Screening detected 66 other patients with a serum thyroid stimulating hormone concentration of 


\begin{tabular}{|c|c|c|c|c|c|c|c|c|c|c|c|}
\hline $\begin{array}{l}\text { Case } \\
\text { No }\end{array}$ & $\begin{array}{c}\text { Sex and } \\
\text { age } \\
\text { (years) }\end{array}$ & $\begin{array}{l}\text { Thyroid } \\
\text { stimulating } \\
\text { hormone } \\
(\mathrm{mL} / \mathrm{l})\end{array}$ & $\begin{array}{c}\text { Free } \\
\text { thyroxine } \\
\text { (pmol/l) }\end{array}$ & $\begin{array}{l}\text { Thyroxine } \\
(\mathrm{nmol} / \mathrm{l})\end{array}$ & $\begin{array}{c}\text { Free } \\
\text { triiodothyronine } \\
(\mathrm{pmol} / \mathrm{l})\end{array}$ & $\begin{array}{l}\text { Triiodothyronine } \\
(\mathrm{nmol} / \mathrm{l})\end{array}$ & $\begin{array}{l}\text { Thyroid } \\
\text { stimulating } \\
\text { hormone } \\
\text { receptor } \\
\text { antibodies } \\
\text { (U/l) }\end{array}$ & $\begin{array}{l}\text { Microsomal } \\
\text { antibodies } \\
(\mathrm{kU} / \mathrm{l})\end{array}$ & $\begin{array}{c}\text { Thyroxine } \\
\text { binding } \\
\text { globulin } \\
(\mathrm{mg} / \mathrm{l})\end{array}$ & $\begin{array}{l}\text { Thyroid } \\
\text { stimulating } \\
\text { hormone } \\
\text { releasing } \\
\text { hormone } \\
\text { test } \dagger\end{array}$ & $\begin{array}{l}\text { Clinical } \\
\text { diagnosis }\end{array}$ \\
\hline \multicolumn{12}{|c|}{ Hyperthyroidism requiring treatment } \\
\hline 1 & F 61 & Undetectable & 29 & 150 & $10 \cdot 0$ & $3 \cdot 5$ & $7 \cdot 6$ & 540 & 23 & 0 & Single toxic adenoma \\
\hline 2 & F 67 & Undetectable & 37 & 158 & $14 \cdot 0$ & $3 \cdot 3$ & $1 \cdot 1$ & $<50$ & 17 & 0 & Multinodular toxic goitre \\
\hline 3 & F 77 & Undetectable & 28 & 145 & $8 \cdot 8$ & $2 \cdot 5$ & $0 \cdot 5$ & 1100 & 20 & 0 & Multinodular toxic goitre \\
\hline \multicolumn{12}{|c|}{ No treatment } \\
\hline 4 & M 25 & Undetectable & 22 & $\ddagger$ & $\ddagger$ & $2 \cdot 3$ & $\ddagger$ & $<50$ & $\ddagger$ & $\ddagger$ & Subacute thyroiditis \\
\hline 5 & F 28 & Undetectable & 24 & 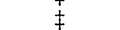 & $\ddagger$ & $2 \cdot 7$ & $\neq$ & $<50$ & $\underset{f}{+}$ & $\stackrel{+}{\neq}$ & Postpartum thyroiditis \\
\hline 6 & F 59 & $0 \cdot 170$ & 20 & 109 & $7 \cdot 8$ & $2 \cdot 5$ & $2 \cdot 8$ & $<50$ & 21 & $\stackrel{+}{0}^{+}$ & Multinodular goitre \\
\hline 7 & F 61 & $0 \cdot 195$ & 17 & 99 & $7 \cdot 0$ & $2 \cdot 7$ & 1.9 & $<50$ & 22 & 0 & Multinodular goitre \\
\hline
\end{tabular}

*Decision limits used in study: thyroid stimulating hormone $0 \cdot 2-4 \cdot 0 \mathrm{mU} / 1$; free thyroxine $9 \cdot 0-21 \cdot 0 \mathrm{pmol} /$; thyroxine $60-150 \mathrm{nmol} / \mathrm{l}$; free triiodothyronine $3 \cdot 5-8 \cdot 5 \mathrm{pmol} / 1$; triiodothyronine $1 \cdot 5-2 \cdot 8$ $\mathrm{nmol} / \mathrm{l}$; thyroid stimulating hormone receptor antibodies $<10 \cdot 0 \mathrm{U} / \mathrm{l} ;$ microsomal antibodies $<50 \mathrm{kU} / \mathrm{l}$; thyroxine binding globulin $14-26 \mathrm{mg} / \mathrm{l}$.

+Protirelin stimulation test; $0=$ non-responders.

łAssay not performed.

AAssay of follow up samples including protirelin stimulation test showed undetectable values.

$\leqslant 0 \cdot 20 \mathrm{mU} / \mathrm{l}$, who did not have evidence of thyroid disease (table III). Whereas at recall after two to three weeks the thyroid stimulating hormone concentration was unchanged or lower in all patients with thyroid disease, this was so in only 20 out of 48 patients without thyroid disease (table III), values up to $2 \cdot 3 \mathrm{mU} / \mathrm{l}$ being found in the remainder. All 29 patients with repeatedly low serum thyroid stimulating hormone concentrations (table III) were offered a protirelin test and 21 accepted. Of these patients, 13 showed a positive response (rise in thyroid stimulating hormone concentration of $0 \cdot 11-5 \cdot 6$ $\mathrm{mU} / \mathrm{l})$, of whom five with a repeatedly undetectable basal thyroid stimulating hormone concentration responded with a rise of $0.36-1.5 \mathrm{mU} / 1$. There was no response (rise $<0 \cdot 10 \mathrm{mU} / \mathrm{l}$ ) in eight patients, including the three with hyperthyroidism (cases 1-3), two with multinodular goitre (cases 6 and 7), and one with chronic active hepatitis with high concentrations of microsomal antibodies but no other evidence of thyroid disease (table III); one patient with upper respiratory tract infection and borderline to high thyroid hormone concentrations but no evidence of thyroid disease during one year follow up; and one woman receiving ibuprofen for mild arthritis, whose suppressed thyroid stimulating hormone secretion returned to normal after withdrawal of the drug.

Of the patients with raised serum thryoid stimulating hormone concentrations, 15 women and one man were found to have spontaneous autoimmune hypothyroidism.

TABLE V-Indications for thyroxine replacement in 98 patients of various ages

\begin{tabular}{|c|c|c|c|c|c|c|c|}
\hline \multirow[b]{3}{*}{$\begin{array}{l}\text { Age } \\
\text { (years) }\end{array}$} & \multicolumn{6}{|c|}{ Indication for thyroxine } & \multirow[b]{3}{*}{ Total } \\
\hline & \multirow[b]{2}{*}{$\begin{array}{l}\text { Spontaneous } \\
\text { hypothyroidism }\end{array}$} & \multirow[b]{2}{*}{$\begin{array}{c}\text { Euthyroid } \\
\text { goitre }\end{array}$} & \multicolumn{2}{|c|}{$\begin{array}{l}\text { Hypothyroidism after } \\
\text { thyrotoxicosis }\end{array}$} & \multirow{2}{*}{$\begin{array}{c}\text { Non-toxic } \\
\text { goitre } \\
\text { (operated) }\end{array}$} & \multirow[b]{2}{*}{ Other } & \\
\hline & & & Operated & $\begin{array}{l}\text { Treated with } \\
\text { radioiodine }\end{array}$ & & & \\
\hline$\leqslant 19$ & 0 & 0 & 0 & 0 & 0 & 0 & 0 \\
\hline $20-29$ & 2 & 1 & 0 & 0) & 0 & 0 & 3 \\
\hline $30-39$ & 6 & 1 & 1 & 0 & 0 & 0 & 8 \\
\hline $40-49$ & 10 & 2 & 4 & 0 & 0 & 0 & 16 \\
\hline $50-59$ & 13 & 1 & 5 & 2 & 7 & 1 & 29 \\
\hline $60-69$ & 10 & 1 & 1 & 3 & 3 & 1 & 19 \\
\hline $70-79$ & 8 & 4 & 2 & 2 & 2 & 1 & 19 \\
\hline$\geqslant 80$ & 3 & 0 & 0 & 1 & 0 & 0 & 4 \\
\hline Total & 52 & 10 & 13 & 8 & 12 & 3 & 98 \\
\hline
\end{tabular}

TABLE VI-Age at onset of treatment with thyroxine

\begin{tabular}{ccccccccccc}
\hline & \multicolumn{10}{c}{ Age (years) } \\
\cline { 2 - 9 } & $\leqslant 9$ & $10-$ & $20-$ & $30-$ & $40-$ & $50-$ & $60-$ & $70-$ & $\geqslant 80$ & Total \\
\hline No of patients & 0 & 6 & 15 & 20 & 23 & 19 & 7 & 5 & 0 & $95 *$ \\
\hline
\end{tabular}

^Information lacking in three cases.
In 35 patients with no previous history of thyroid disease the clinician in charge at the time of screening recorded a clinical impression of slight or overt hyperthyroidism or hypothyroidism; in none of these patients was the clinical suspicion verified biochemically.

Thus screening 2000 consecutive patients disclosed 21 with previously undiagnosed thyroid dysfunction (hyperthyroidism or hypothyroidism) needing treatment $(n=19)$ or surveillance $(n=2)$. Of these patients, six were attending the centre for acute disorders and 15 for routine care, none having disorders obviously related to their abnormal thyroid function. Of 68 patients not receiving thyroxine who had a serum thyroid stimulating hormone concentration of $0.20 \mathrm{mU} / \mathrm{l}$ or less, only nine had thyroid disease. Of 15 patients with consistently undetectable basal thyroid stimulating hormone concentrations, five showed a positive response to protirelin, three had no detectable thyroid disease, and only three needed antihyperthyroid treatment.

\section{PATIENTS RECEIVING THYROXINE}

In the cross sectional study we found 98 patients being treated with thyroxine, the main indications being spontaneous hypothyroidism $(n=52)$ and hypothyroidism occurring after thyrotoxicosis $(n=21)$. Table $\mathrm{V}$ lists the indications for thyroxine in the different age groups, and table VI shows the age at which treatment began. The most common age at onset of treatment was $40-49$ years, only 41 patients having begun treatment before that age. The mean age at beginning thyroxine was 42 (SD 15) years and the mean age of patients taking thyroxine at the time of screening 56 (15) years. Forty six patients receiving thyroxine were also being treated for other diseases, the most common being cardiac decompensation $(n=14)$, diabetes mellitus $(n=7)$, arterial hypertension $(n=7)$, obstructive pulmonary disease $(n=5)$, rheumatoid arthritis $(n=3)$, and pernicious anaemia $(n=2)$. Nine patients receiving thyroxine attended the centre more than one a year for their thyroid disease.

Seventy one of the 2000 patients subjected to screening were receiving thyroxine. Of these, only 25 had serum thyroid stimulating hormone concentrations of $0 \cdot 20-4 \cdot 0 \mathrm{mU} / \mathrm{l}$. Low concentrations $(\leqslant 0.20 \mathrm{mU} / \mathrm{l})$ were found in 39 patients and high concentrations $(>4.0 \mathrm{mU} / \mathrm{l})$ in seven. One patient had a thyroid stimulating hormone concentration of $71 \mathrm{mU} / \mathrm{l}$ but was clinically euthyroid. Raised serum free thyroxine concentration $(\geqslant 21.0 \mathrm{pmol} / \mathrm{l})$ was found in 39 patients, 11 having values of $\geqslant 30.0 \mathrm{pmol} / \mathrm{l}$. A single patient had a raised serum triiodothyronine concentration $(3 \cdot 1 \mathrm{nmol} / \mathrm{l})$ indicating autonomous thyroid function ${ }^{10}$ (verified by scintigraphy). In this 
patient serum thyroid stimulating hormone was undetectable, the free thyroxine concentration was $48 \mathrm{pmol} / \mathrm{l}$, and the free triiodothyronine concentration was $14 \mathrm{pmol} / \mathrm{l}$. She also was classified as euthyroid. Thus a pronounced biochemical abnormality was found in two of the 71 patients, and both were classified as euthyroid.

Of 30 patients receiving thyroxine who were recalled, 28 returned and had their blood sampled before their daily dose of the drug. In 16 cases the serum thyroid stimulating hormone concentration was between $0 \cdot 20$ and $4.0 \mathrm{mU} / \mathrm{l}$, and in 12 cases the concentration was $\leqslant 0.20 \mathrm{mU} / \mathrm{l}$. Seven patients had a serum free thyroxine concentration $\geqslant 21.0 \mathrm{pmol} / \mathrm{l}$, but in none did the value exceed $30 \mathrm{pmol} / \mathrm{l}$.

\section{Discussion}

All primary care in Mölnlycke is provided by the primary care centre, and no private doctors practise in the area. There is an affiliated 600 bed county hospital, to which patients with severe hyperthyroidism and hypothyroidism are admitted as well as patients for thyroid surgery. Most of these patients, however, are seen initially at the primary care centre and return to the centre once treatment in hospital is completed (see table $\mathrm{V}$ ). In accordance with government policy in Sweden increasing numbers of patients with thyroid disease have been managed in primary care centres over the past few years.

In this series biochemical screening detected 21 patients with previously undiagnosed thyroid disease needing treatment or surveillance. They represented virtually $1 \%$ of the patients screened, which agreed with our findings in a survey among short stay hospital medical patients and outpatients. ${ }^{+}$The patients, mostly women, were attending the centre either for acute conditions or for routine care of non-thyroid disease and in no case were there symptoms that we could attribute to thyroid disease. In patients with only slightly raised serum thyroid stimulating hormone concentrations, thyroid hormone concentrations within reference limits, and no obvious signs or symptoms suggesting hypothyroidism it is not possible to verify a diagnosis of thyroid dysfunction until after at least six months of treatment, ${ }^{11}$ and this was so in the study. As further evidence of the difficulty of diagnosing thyroid dysfunction clinically, in none of 35 patients in whom the disease was suspected clinically did biochemical evaluation confirm the diagnosis.

Ninety eight patients were receiving thyroxine supplementation at the centre, in half of them this being their only reason for contact with the centre. These patients had a mean age of 56 years and had begun thyroxine supplementation at a mean age of 42 . In Sweden the average life expectancy at the age of 56 is roughly 24 years (21 years for men, 26 years for women), so that these patients may be expected to be needing management by the centre for many years.

Though the efficacy of thyroxine treatment is usually evaluated clinically, our finding patients with hitherto unrecognised thyroid autonomy as well as a patient with a high thyroid stimulating hormone concentration indicating poor therapeutic compliance underlines the value of biochemical testing. Nevertheless, it is important to tell the patient to take his or her daily dose of thyroxine after blood sampling. This is illustrated by our finding a high free thyroxine concentration $(\geqslant 21$ $\mathrm{pmol} / \mathrm{l}$ ) in over half the patients whose blood was sampled without reference to the time of dosing as compared with only a quarter of patients given proper instructions. We also cannot exclude the possibility that temporary inhibition of conversion of thyroxine to triiodothyronine due to non-thyroidal illness may have been a factor in the high free thyroxine concentrations noted in some patients receiving thyroxine. Hence results of biochemical determinations in a patient taking thyroxine might also be misleading if the sample has been taken without consideration of the general state of health.

This study highlights the importance of a rational choice of a low decision limit for serum thyroid stimulating hormone concentration when using the new generation of thyroid stimulating hormone assays in general clinical practice - that is, outside specialised thyroid clinics. Judged from information available on the present assay at the start of the study a value of $0.40 \mathrm{mU} / 1$ seemed appropriate. It soon became apparent that if we used this limit an unduly large number of patients would have to be recalled. The possibility that performance of the assay might cause a negative bias of thyroid stimulating hormone values was ruled out in separate experiments with controls and diluted reference preparations supplied by the manufacturer. Our results showed that reference limits for euthyroid people obtained by conventional procedures - that is, by selecting apparently healthy subjects-were inappropriate as a basis for defining decision levels for thyroid stimluating hormone assays in clinical practice, as a large proportion of our patients with only minor non-thyroidal illness had lower thyroid stimulating hormone concentrations than those reported for euthyroid people. Our low limit of $0.20 \mathrm{mU} / 1$ was selected from, among other things, considerations of the imprecision of the assay. Though precision was poor at low thyroid stimulating hormone concentrations, it compared favourably with that of other presently available assays, ${ }^{1213}$ and with this limit there was little risk that hyperthyroid patients would go undetected provided that they did not have heterophilic antibodies interfering with the assay. ${ }^{14}$ In only one of our 2000 patients did we find a spurious rise $(5 \mathrm{mU} / \mathrm{l})$ in a euthyroid patient with a thyroid stimulating hormone concentration of about $1 \mathrm{mU} / \mathrm{l}$, determined with two immunoradiometric assays and one radioimmunoassay.

Our finding five patients with repeatedly undetectable basal thyroid stimulating hormone concentrations who had a clear thyroid stimulating hormone response to protirelin agrees with the results of Spencer et al in thyroxine treated patients. ${ }^{15}$ Spencer et al concluded that present generally available thyroid stimulating hormone assays cannot safely exclude the presence of significant thyroid stimulation by thyroid stimulating hormone despite the low detection limits. Thus suppressed thyroid stimulating hormone secretion in a single patient cannot be diagnosed at present from basal measurements alone, though in mixed patient populations there is a correlation between basal and protirelin stimulated thyroid stimulating hormone secretion. ${ }^{16}$

Reports on detection limits of the "new generation" thyroid stimulating hormone assays have paid little attention to assay performance at low thyroid stimulating hormone concentrations, either analytically or clinically ${ }^{17-19}$ For instance, judging from the precision profile in a recent report of a mulicentre study on 10 such methods only one had a within assay coefficient of variation of less than $10 \%$ at thyroid stimulating hormone concentrations of up to $0.70 \mathrm{mU} / 1 .{ }^{13} \mathrm{Im}$ precision with solutions used for calibration or with commercially available controls may be different from that with patients' specimens, so it is unfortunate that published information is often poor in this respect. In the face of the low clinical specificity of low thyroid stimulating hormone concentrations measured by current methods we must resort to determining circulating thyroid hormone concentrations for evaluating the clinical relevance of a low thyroid stimulating hormone concentration; also the sensitivity of 
immunometric assays to heterophilic antibodies calls for the availability of thyroid hormone measurements when finding a normal or raised thyroid stimulating hormone concentration in cases of suspected hyperthyroidism. A notable achievement with recent assays (to our knowledge not discussed previously) is the increased analytical specificity at the upper end of the distribution - say, the 3-6 mU/l range-at which these assays, in conjunction with modern ligand assays of microsomal antibodies, permit a more reliable diagnosis of autoimmune thyroid disease of potential clinical importance versus adaptive increase in thyroid stimulating hormone secretion after disease (findings to be published).

This study also highlights the problems associated with interpreting the results of the protirelin stimulation test. Before the introduction of the new generation of thyroid stimulating hormone assays an incremental rise in serum thyroid stimulating hormone of 1.0-2.0 $\mathrm{mU} / \mathrm{l}$ after an injection of protirelin was often used as the detection limit. In this investigation of patients with basal thyroid stimulating hormone concentrations of $\leqslant 0.20 \mathrm{mU} / 1$ we chose an increment of $\geqslant 0.1 \mathrm{mU} / \mathrm{l}$ in the samples at 20 and 30 minutes after injection compared with the mean of the two basal values. Thus any rise of thyroid stimulating hormone was considered to exclude thyroid autonomy. Consequently, some patients classified as not having autonomous thyroid function in our study would have been classified differently in studies at other centres.

Low serum thyroid stimulating hormone concentrations in patients without thyroid disease have been recorded in hospitalised, often severely sick patients, ${ }^{16}{ }^{19-25}$ in some cases as a result of drug treatment (see below). Table III shows that temporary suppression may also be detected in outpatients with less severe medical disorders. Whether this suppression in non-thyroidal illness is due to hypothalamic dysfunction ${ }^{21}$ or is a result of pituitary inhibition by increased free thyroxine concentration ${ }^{25}$ is unknown, as was the cause of the rebound increase seen during recovery from non-thyroidal illness ${ }^{21}$ and after withdrawal of thyroxine in a trial of treatment of subclinical hypothyroidism."

Gow $e t$ al and Caldwell $e$ t al advocated using an assay of serum thyroid stimulating hormone with a low detection limit as a first test in evaluating thyroid function..$^{1626}$ Other workers disagree, however, ${ }^{19} 2023$ and it appears that in many cases severe methodological problems exist. ${ }^{182}$ Besides non-thyroidal illness the influence of biological variation, ${ }^{28}$ early pregnancy, ${ }^{29}$ fasting ${ }^{30}$ drug treatment (corticosteroids, ${ }^{31}$ dopamine ${ }^{25}$ ), endogenous depression, ${ }^{32}$ exercise, ${ }^{33}$ and, in the case of thyroxine supplementation, time of drug intake ${ }^{5}$ may all have been underestimated. Several of these factors may have influenced results in this series, in which a surprisingly large number of patients without thyroid disease had low serum thyroid stimulating hormone concentrations. That in a large proportion of patients with concentrations of $\leqslant 0.20 \mathrm{mU} / 1$ who did not have thyroid disease a considerably higher value was found two to three weeks after screening may also have been related to factors such as intraindividual biological variation, recovery from disease, and change or withdrawal of drug treatment.

Our study shows that a large number of patients were attending the primary care centre for long term management of thyroid disease. In most cases their care followed an established routine, the patients seeing the doctor only once a year in the absence of other diseases. In addition to these patients, however, a surprisingly large number of clinically undiagnosed cases of thryoid dysfunction were identified biochemically and at a subsequent clinical follow up evaluation after six months. Though these findings may support screening for thyroid disease-for example, in selected groups of the population or in patients attending medical departments - following up all patients with abnormal test results would be impracticable. Nevertheless, we suggest that thyroid function should be tested every two to five years in all women over 40-50 years of age attending these centres for routine care and in women of the same age after treatment for acute diseases, either when the acute stage of the disease has passed or at a subsequent follow up appointment. Doctors should therefore be aware of the metabolic changes that occur in the hypothalamuspituitary-thyroid system ${ }^{1822}$ during and after disease if the results are to be interpreted correctly. ${ }^{34}$ Basal thyroid stimulating hormone measurements alone by present methods are insufficient for the initial biochemical assessment of thyroid dysfunction in unselected outpatient populations.

We thank the following general practitioners and residents at Mölnlycke Primary Care Centre who contributed to the study: Thorkil Andersen, Margareta Ekman-Svensk, Lennart Holmström, Robert Siöstedt, Lotta Dahr, Anne Haglund, Märt Henning, Kathleen Malloy. We also thank laboratory assistant Lena Wejkum for excellent technical work and nurses Ulla Lapidus and Birgitta Lange and the nursing staff at the primary care centre for their help and support. Abbott Laboratories (Chicago) and Diagnostic Products Corporation (Los Angeles) generously supplied reagents and instruments.

1 Tunbridge WMG, Evered DC, Hall R, et al. The spectrum of thyroid disease in a community: the Whickham survey. Clin Endocrinol 1977;7:481-93.

2 Kendall-Taylor P, Keir MJ, Ross WM. Ablative radioiodine therapy for hyperthyroidism: long term follow up study. Br Med J 1984;289:361-3.

3 Kågedal B, Månson JC, Norr A, Sörbo B, Tegler L. Screening for thyroid disorders in middle-aged women by computer-assisted evaluation of a thyroid hormone panel. Scand F Clin Lab Invest 1981;41:403-8.

4 Nyström E, Petersen K, Lindstedt G, Lundberg P-A. Screening for thyroid disease in women $\geqslant 50$ years of age seeking hospital care: influence of common non-thyroidal illness on serum free thyroxin as determined by common non-thyroidal illness on serum free thyrox
analog radioimmunoassay. Clin Chem 1986;32:603-8.

5 Soppi E, Irjala K, Kaihola H-L, Viikari J. Acute effect of exogenous thyroxine dose on serum thyroxine and thyrotropin levels in treated hypothyroid patients. Scand 7 Clin Lab Invest 1984;44:353-6.

6 Kubasik NP, Lundberg P-A, Brodows RG, et al. Free thyroxin by radioimmunoassay: evaluation of a new direct method involving a radiolabelled thyroxin analog. Clin Chem 1983;29:1781-6.

7 Allan DJ, Murphy F, Needham CA, Barron N, Wilkins TA, Midgley JEM Sensitive test for thyroid hormone antibodies in serum. Lancet 1982;ii:824.

8 Lindstedt G, Lundberg P-A, Sjögren B, Ernest I, Sundquist O. Thyroid hormone resistance in a 35 -year old man with recurrent goitre. Scand $7 \mathrm{Clin}$ Lab Invest 1982;42:585-93.

9 Lindstedt G, Tisell LE, Nyström E, Petersen K, Jagenburg R, Lundberg P-A. Thyroid evaluation in the mid '80s. Scand $\mathcal{F}$ Clin Invest 1984;44:465-70.

10 Pearce CJ, Himsworth RL. Total and free thyroid hormone concentrations in patients receiving maintenance replacement treatment with thyroxine.

11 Nyström E, Caidahl K, Fager G, Wikkelsö C, Lundberg P-A, Lindstedt G. A double-blind cross-over 12 -month study of $\mathrm{L}$-thyroxine treatment of women with "subclinical" hypothyroidism. Clin Endocrinol 1988;29:63-76.

12 Evans MC. Ten commercial kits compared for assay of thyrotropin in the normal and thyrotoxic range. Clin Chem 1988;34:123-7.

13 Thonnart B, Messlan O, Linhart NC, Bok B. Ten highly-sensitive thyrotrophin assays compared by receiving operating characteristic curves analysis: results of a prospective multicenter study. Clin Chem 1988;34:691-5.

14 Boscato LM, Stuart MC. Heterophilic antibodies: a problem for all immunoassays. Clin Chem 1988;34:27-33.

15 Spencer CA, Lai-Rosenfeld AO, Guttler RB. Thyrotrophin secretion in thyrotoxic and thyroxine-treated patients: assessment by a sensitive immunoenzymometric assay. I Clin Endocrinol Metab 1986;63:349-55.

16 Gow SM, Elder A, Caldwell G, et al. An improved approach to thyroid function testing in patients with non-thyroidal illness. Clin Chim Acta $1986 ; 158: 49-58$

17 Weeks I, Woodhead JS. A further comment on measurement of thyrotropin. Clin Chem 1985;31:161-2.

18 Nyström E, Lindstedt G, Lundberg P-A. The new generation of thyrotropin assays - their place in thyrodiagnostic strategy. Scand F Clin Lab Invest 1986;46:197-9.

19 Spencer C, Eigen A, Shen D, et al. Specificity of sensitive assays of thyrotropin (TSH) used to screen for thyroid disease in hospitalized patients. Clin Chem 1987;33:1391-6.

20 Dubuis JM, Burger AG. Thyroid-stimulating hormone measurements by immunoradiometric assays in severely ill patients. Lancet 1986;ii:1036-7.

21 Hamblin PS, Dyer SA, Mohr VS, et al. Relationship between thyrotropin and thyroxine changes during recovery from severe hypothyroxinemia of critical illness. F Clin Endocrinol Metab 1986;62:717-22.

22 Wehman R, Gregerman RI, Burns WH, Saral R, Santos GW. Suppression of thyrotropin in the low-thyroxine state of severe nonthyroidal illness. $N$ Engl
fMed 1985;312:546-52.

23 Ericsson U-B, Fernlund P, Thorell JI. Evaluation of the usefulness of a sensitive immunoradiometric assay for thyroid stimulating hormone as a 
first-line thyroid function test in an unselected patient population. Scand $f$ Clin Lab Invest 1987; 47:215-21.

24 Rönnov-Jessen D, Skov L, Faber J. Immunoradiometric assay of serum thyroid stimulating hormone (TSH) as a first-line test in a mixed hospital population. Clin Chim Acta 1987;168:13-7.

25 Faber J, Kirkegaard C, Rasmussen B, Westh H, Busch-Sorensen M, Jensen IW. Pituitary-thyroid axis in critical illness. F Clin Endocrinol Metab
$1987: 65: 315-20$

26 Caldwell G, Kellet HA, Gow SM, et al. A new strategy for thyroid function testing. Lancet 1985;i:1117-9.

27 Klee GG, Hay ID. Assessment of sensitive thyrotropin assays for an expanded role in thyroid testing: proposed criteria for analytic performance and clinical urlity $\gamma$ Clin Endoping $1987,64: 461-71$.

28 Browning MCK, Ford RP, Callaghan SJ, Frazer CG. Intra- and interindividual biological variation of five analytes used in assessing thyroid function: implications for necessary standards of performance and the interpretation of results. Clin Chem 1986;32:962-6.

29 Gow SM, Kellet HA, Seth J, Sweeting VM, Toft AD, Becket GJ. Limitation of a new thyroid function test in pregnancy. Clin Chim Actu $1985 ; 152: 325-33$

30 Borst CG, Osburne RC, O'Brian JT, (jeorges LP, Burman KD). Fasting decreases thrrotropin responsiveness to thrrotropin-releasing hormone: potential cause of misinterpretation of thvroid function tests in the critically ill. 7 Clin Endocrinol Metab 1983;57:380-3.

31 Otsuki M, Dakoda M, Baba S. Influence of glucocorticoids on TRF-induced TSH response in man. $\mathcal{F}$ Clin Endocrinol Metab 1973;36:95-102.

32 Piketty M-L, Talbot J-M, Askienazy S, Milhaud G. Clinical significance of a low concentration of thyrotropin: five immunometric "kit" assays. Clin Chem 1987:33:1237-41.

33 Krotkiewski M, Siöström L, Sullivan L, et al. The effect of acute and chronic exercise on thyroid hormones in obesity. Acta Med Scand 1984;216:269-75 34 Toft AD, Seth J. Sensitive thyrotropin assays: excellent when properly used. Br.Med f 1987;295:1503.

Accepted 27 September 1988

\section{MULTICULTURAL MEDICINE}

\section{Beware of dried fruit inflation}

Bulk purgatives contain plant fibre such as bran, ispaghula, or sterculia Synthetic agents such as methylcellulose can also keep colonic contents on the move. They absorb water, thereby increasing the volume of the stools and so softening the faeces. Adequate hydration is advised when taking such tablets or granules.

Constipation is common in Western societies because of low fibre diets, and it is such a terrible thing that it is written all over the face of the chronic sufferer. A consultant geriatrician often teaches the house officer and night nurse that "if you keep the patient's bowels open he will keep his mouth shut." Being "bunged up" is such an uncomfortable feeling that people will resort to anything-drugs, herbs, and health foods-and they often eat dried figs and apricots. Beware, there is a danger.

Wu and Copeland have reported that a 61 year old woman presented with an obstruction of the small intestine, and through a proximal ileostomy a $3 \mathrm{~cm}$ wide, fresh looking apricot was removed.' She insisted that she had never swallowed such a fruit, but her daughter had presented her with a packet of dried apricots three days before her illness. The authors said that a dried apricot soaked in water for 24 hours will swell to the size of a fresh apricot and retailers of dried fruit should display a health warning: "Not to be swallowed whole or it may turn into a jam."

Moslems eat dried dates (chohara) as a religious delicacy. A dried date is the substitute for a fig or an apricot. It is customary to break the daily fast in the month of Ramadan with fresh or dried dates. At a marriage

\section{Interesting misunderstandings}

\section{Canadian notepaper}

Like Australians, Canadians are well known for their love of the British monarchy, and a Canadian doctor will hardly ever miss the chance to present a paper at a meeting in Britain organised by a royal college if invited. On one occasion an English royal college organised a three day international conference: a keynote speaker was chosen from the World Health Organisation; 18 main speakers for six sessions were chosen from various countries; as a side show, 36 free standing papers were planned, to be presented in a room adjacent to the main conference hall; and 50 posters on different medical topics were planned for display in the corridors. The speakers and poster authors were invited from all over the world to send abstracts for consideration.

A Canadian doctor wrote his forwarding letter on the notepaper of a Canadian national college and sent an abstract for a freestanding paper. This caused confusion because if he was to represent a national college, according to the policy of the organising committee, his paper should be accepted and the house staff would help him to bring it up to the required standard if necessary. But if he was speaking for himself then his abstract had to be judged on open merit. The president of the English college rang the president of the Canadian national college to inquire if the doctor was representing that college. The Canadian president denied any college connection with the doctor, except that he was an ordinary member, and was annoyed with the Canadian doctor. Both presidents thought he was trying to pull the wool over their eyes. The organising committee were up ceremony, during a pilgrimage to Mecca (Hadj), and to celebrate the anniversary of the death of a holy man dates are distributed among all the guests. Elderly Moslems feel spiritually attached to this holy fruit which causes such physical relief. No wonder they look happy.

Moslems returning from Hadj often bring dried dates as presents for relatives, friends, and the doctor, even if he or she is a European. It is true that the Moslem faith has generated a world. It is estimated that in 1950 every seventh human being was a Moslem and in 1985 every fifth human being followed Islam or bore its name. ${ }^{2}$ It is the second largest religion in Britain and Russia, and the third largest faith in the United States. There are about two million Moslems in Britain (and 515 mosques with attached schools). They immigrated from Arabian, Asian, and south east Asian countries.

A hakim (Moslem herbalist) always considers "dried dates" in the differential diagnosis of acute abdomen but does not ask about figs. In these days of increasing transcultural contact it is essential that a European doctor asks about dried dates and an Eastern physician should not forget to ask about dried apricots. People are using more health foods than ever before and every doctor must bear in mind dried fruits as a possible cause of intestinal obstruction.

1 Wu AVO, Copeland G. Views. Br.Med f 1988:297:568

2 Rahman $\mathrm{F}$. Health and medicine in the Islamic tradition. New York: Crossroad, 1987: in arms, and his paper was nearly rejected on ethical grounds. Fortunately, a committee member spotted the cultural misunderstanding between Britain and the Commonwealth, and the paper was rejudged.

In Britain members of a royal college do not use its notepaper. This is used exclusively by its officers, and no rubber stamp is necessary, whereas it is customary in almost all the Commonwealth countries for members to use the college notepaper, as they would wear a college tie, scarf, or cufflinks, and a letter is considered official only if an officer of the college puts a rubber stamp under his or her signature.

\section{Eastern visiting card}

The Royal Society of Medicine is a prestigious institution in the United Kingdom. Wednesday 2 July 1986 was a royal occasion and Her Majesty the Queen opened the society's new building. Many members attended the event, and some exchanged visiting cards with each other. An English member showed the visiting card from an Egyptian member to an Asian colleague, pointing out that it bore the curriculum vitae of the Egyptian doctor! The westernised Asian laughed and told him of a difference in thinking. In the West a doctor's visiting card simply bears his or her name and address, and it is a courtesy to exchange cards but customary not to follow this up. In Eastern cultures, however, a doctor's visiting card bears not only all his diplomas but also important past appointments, and worse still, he may try to call. You have been warned. - BASHIR QURESHI, general practitioner, Hounslow, London 